\title{
NOTES ON A CLAY MOULD FOR BROOCH CASTING RECENTLY DISCOVERED FROM THE GREAT HUNGARIAN PLAIN
}

\begin{abstract}
The object herein is the examination of the clay mould for brooch casting discovered in site 7 of Ecser (Hungary), investigated during May 2004 - June 2006 by rescue archaeological excavations performed prior to the construction of the express road M0, a bypass of Budapest. The mould was found in feature 4180 linked to the 3rd century AD Sarmatian settlement. Based on the morphological analysis of the Ecser mould, the author notes it was used for making brooches type Almgren group VII, series I, the headknob variation, external chord and vertical catchplate and by no means a pattern for casting Roman brooches. The recent typological analysis of brooches of the type shows that the mould was used for making brooches type Cociș-Bârcă B2a1a1, mainly used between the last two decades of the 2nd century $A D$ and mid 3rd century AD.

The presence of the mould in the settlement at Ecser evidences the production of brooches of type Almgren group VII, series I, the headknob variation, external chord and vertical catchplate (B2a1a1) in territories inhabited by the Sarmatians in the Great Hungarian Plain, as well as an existing workshop for their making nearby.

Based on the origin, diffusion area of these brooches and the workshops producing them, but also certain historical and archaeological realities, the author maintains that the making of such brooches in the settlement at Ecser must be ascribed rather to an artisan arriving to the territory inhabited by the Sarmatian Iazyges or in connection with the Germanic world.

The frequent presence of brooches of the type beside other brooch types and Germanic artefact categories evidence contacts and cultural and economic interferences between various populations, but it also very clearly establishes the movement direction of certain groups of Germanic populaces starting with the last quarter of the 2nd century AD.
\end{abstract}

Keywords: workshops, brooches, bronze, moulds, half-finished, the Sarmatians, the Vandals, Dacia, Przeworsk, Barbaricum.

B rooches are a particular class among jewellery and dress accessories and count as ones of the most precious artefacts in various ancient ethno-cultural areas. They fulfil both a functional and decorative function, being frequently used in the cultural exchanges between various populaces in different regions. Also, as mentioned elsewhere, they provide multiple data on various aspects of the economic and social life, fashion, ethnical aspects and are dating elements aiding a more accurate chronological framing of an entire series of other broadly dated artefact categories or for

\section{Vitalie Bârcă}

Institute of Archaeology and Art History of Cluj-Napoca vitalie_barca@yahoo.com

DOI: $10.14795 /$ j.v6i3.446

ISSN 2360 - 266X

ISSN-L 2360 - 266X 
which chronological criteria are uncertain. Lastly, they are mass produced artefacts that mirror a certain degree of economical and social structuring ${ }^{1}$.

The making of respective jewellery and dress items, as stated elsewhere ${ }^{2}$, entailed mastership of varied technological procedures, even the more so as the artisans made them of various metals. The craftsman had to master rather advanced skills for choosing an alloy with optimal melting temperature that would not destroy the mould and allow precise detachment of all brooch parts, yet also other types of technology (lost-wax casting). Furthermore, the silvering, pearling, spring making, polishing, incise decorating and repairing required vast technological skills ${ }^{3}$.

Between 2001 and 2006, rescue archaeological excavations were carried out prior the construction of the express road M0, a bypass way of Budapest. On this occasion, several archaeological sites were discovered and researched, among them, the site 7 of Ecser investigated between May 2004 and June 2006. The archaeological excavations, which covered a surface of $87.837 \mathrm{~m}^{2}$ unearthed and examined approximately 7920 features $^{4}$. The largest part of the investigated site is occupied by a Sarmatian settlement and cemetery, both with two chronological stages ${ }^{5}$. The remains that belong to the Sarmatian period also includes feature 4180, in which was identified a clay mould for brooch casting $^{6}$ (Fig. 1/1), which supposes a possible workshop existing nearby. The authors who published the mould image provided no further technical data or other information related to the feature where it was discovered. Nonetheless, they argue that the clay mould of Ecser is, beside other moulds discovered in Sarmatian settlements, a pattern for casting Roman brooches ${ }^{7}$, most representative specimens being mentioned those in the workshop at TiszaföldvárTéglagyár ${ }^{8}$

The morphological analysis of the Ecser mould shows it was used for making brooches of type Almgren group VII, series I, the headknob variation, external chord and vertical catchplate or "Sarmatian" brooches", as termed in the

\footnotetext{
Cf. BÂRCĂ 2006, 120; BÂRCĂ 2011, 7; BÂRCĂ 2014, 107-108.

COCIȘ/BÂRCĂ 2013, 162.

3 VOSS 1998, 312-313.

${ }^{4}$ Cf. KÖVÁRI et alii 2006, 21.

${ }^{5}$ Within the surface of the previous settlement - dated by terra sigillata and other Roman pottery - to the 3rd century AD, a later settlement was formed, likely over the course of the 4 th century $\mathrm{AD}$, characterised by coarse pottery. Of the earlier grave group, it is mentioned to date, based on finds (brooches with external chord, headknob and vertical catchplate (Almgren group VII, series I), disc brooches (Scheibenfibeln), terra sigillata of type Dragendorff 33) to the end of the 2 nd c. - early 3 rd century AD. On top of these graves lies the 4 th century settlement, topped at its turn by the end of the 4th century AD Sarmatian graves (?), the latter being dated beside dress items, also by Roman coinage. Also, it is mentioned that most graves are surrounded by a circular ditch, in which often were discovered later graves, in some cases 3-5, most often of children (KÖVÁRI et alii 2006, 21).

${ }^{6}$ ISHTVANOVICH/KUL'CHAR 2016, 121, 124, Fig. 3/1.

7 ISHTVANOVICH/KUL'CHAR 2016, 121.

8 See for this VADAY 2005, 151-198.

9 The first scholar to term these brooches as of "Sarmatian" type was T. Kolnik. The main specificity of the brooches analysed by T. Kolnik, which he termed "Sarmatian" is the external chord attached in the upper side of the head which often ends with a projecting knob, which in some variations is rendered more schematically, even joining the support (KOLNÍK 1965, 189-199, 232). From that time, in the specialty literature, the scholars would use two terminologies to denominate this brooch type. Thus, some would use the term of brooches
} in group Almgren VII, series I, while others that of "Sarmatian" brooches. specialty literature ${ }^{10}$.

Recently, brooches of the type were the object of a large study tackling the specimens from the province of Dacia and the Barbarian milieu by the Tisza river basin ${ }^{11}$. Based on the rich material existing today, a new typology for the brooches in group Almgren VII, series $I^{12}$ was suggested, starting from T. Kolnik's classification. According to the body and catchplate shape and the attachment of the spring, two main variations were proposed: variation $\mathbf{A}$ (internal chord) and variation $\mathbf{B}$ (external chord). Variation $\mathbf{B}$ was sub-divided based on the chord attachment into B1 (external chord and attachment support) and B2 (external chord and headknob).

S. Cociș and V. Bârcă analysed a number of $\mathbf{7 2}$ brooches in variation B2, establishing based on certain accurate criteria, numerous sub-variations ${ }^{13}$. In the establishment of the typology and the approach of other issues arising from the examination of such brooches, the authors also considered similar specimens scattered on an expanse geographical area and a chronological interval comprised between the last decades of the 2 nd - early 4 th century AD (stages B2/C1-C2).

Subsequent to the careful analysis of the Ecser mould, one may argue that it was used with most certainty for making brooches of type Almgren group VII, series I, headknob variation, external chord and vertical catchplate, which belong to variation B2, subvariation B2a1a1 in the typology drafted by S. Cociș and V. Bârcă ${ }^{14}$.

Regarding the moulds, respectively their negatives from the workshop in the Sarmatian Iazygian environment at Tiszaföldvár-Téglagyár (Hungary) ${ }^{15}$, invoked, beside the Ecser mould, in the support of Roman brooch production ${ }^{16}$ by the Sarmatians from the Great Hungarian Plain, we wish to mention that the examination of the moulds, respectively their negatives for the knee brooches at TiszaföldvárTéglagyár ${ }^{17}$ (Fig. 1/2-4) concluded they clearly evidence the production of a Barbarian type knee brooch variation, not Roman $^{18}$. Based on the two negative types for Barbarian knee brooches ${ }^{19}$, the dating of the workshop at TiszaföldvárTéglagyár was suggested for the timeframe B2/C1, while their making was ascribed rather to an artisan travelling to the territory inhabited by the Sarmatian Iazyges or in connection with the Germanic world ${ }^{20}$.

\footnotetext{
${ }^{10}$ For the complex examination of these brooches see COCIȘ/BÂRCĂ 2014 189-214, with complete bibliography and views expressed in connection with their origin, dating and diffusion.

11 COCIȘ/BÂRCĂ 2014

12 COCIȘ/BÂRCĂ 2014, 196-197.

13 COCIȘ/BÂRCĂ 2014, 196, 209-211.

14 COCIȘ/BÂRCĂ 2014, 196.

15 The house-workshop was sized $3.5 \times 2.8 \mathrm{~m}$. Its highly rich furnishing consisted, among other, of bronze object fragments used for re-melting (coins, pots, appliqués, nails etc.), crucibles and tens of clay mould fragments (VADAY 2005, 160-168, Pl. 2-20). The moulds, respectively their negatives, evidence, according to scholar A. Vaday, the production of strongly profiled brooches (Fig. 1/5), Roman and Germanic knee brooch types (Fig. 1/2-4) Chronologically, the workshop was dated based on the two fragmentary coins (used as raw material) and the brooch types in the moulds to the 2nd century AD (VADAY 2005, 160, 171).

16 ISHTVANOVICH/KUL'CHAR 2016, 121.

17 VADAY 2005, Pl. 8/1.

8 COCISS/BÂRCĂ 2013, 168 .

19 VADAY 2005, Pl. 18/1, 3, 6

20 COCIȘ/BÂRCĂ 2013, 168.
} 
Brooches of type Almgren group VII, series I, variation B2, the sub-variation with headknob, external chord and vertical catchplate are sprung, with an 8-40 coils spring set simple, double or triple. The body of these brooches is sharply bent. On the body surface there are one or two midway ribs, while at the junction with the foot there is often a small necking. The ornaments count the pearling system made either by granulation or the decoration with ridged thread, which thus gives the appearance of pearls. The brooch head is incorporated in the terminal body part and often ends with a projecting knob, which in certain variations is flattened (being rendered rather schematically), even joining (by casting) the support. The fastening support of the spring may have one, two or three orifices depending on the spring type, simple, double or triple. The foot is either short or long, may be faceted and most often ends in a knob. The catchplate is rectangular, short of long, parallel or oblique to the foot. They are made of two pieces, respectively the brooch itself, of a metal piece, and separately, the spring. The metal used in their making is in most cases the bronze, while in a certain stage silver specimens also emerge, or exceptionally, iron ${ }^{21}$ (Cf. Fig. 2-3).

Since brooches of the type are rather rare in the Roman world ${ }^{22}$, we shall briefly mention the views concerning their origin, chronology, distribution area $^{23}$ as well as workshops of clear traces evidencing their production ${ }^{24}$.

Over the course of time, brooches in group Almgren $\mathrm{VII}^{25}$ enjoyed the attention of several scholars ${ }^{26}$, their origin being placed in the Danubian and Rhine provinces (M. Párducz ${ }^{27}$ ), the eastern Germanic world (E. Patek ${ }^{28}$ ), southern Banat and the eastern territories (M. Párducz ${ }^{29}$ ) and the Central-European area by Mid Danube (R. Kenk ${ }^{30}$ ). For Slovakia, T. Kolnik believed we are dealing with a local development ${ }^{31}$, while for the territory of Moravia, their emergence is related by I. Peškař to the contacts between the Quadi and the Sarmatians ${ }^{32}$. A local production of such brooches in the Upper Dniester region is supported by $\mathrm{M}$.

\footnotetext{
${ }^{21}$ COCIȘ/BÂRCĂ 2013, 162 ; COCIȘ/BÂRCĂ 2014, 190; BÂRCĂ 2014, 115.

22 For the finds within the territory of Dacia see COCIȘ/BÂRCĂ 2014, 197, 209.

${ }^{23}$ For an extended analysis of these aspects see COCIȘ/BÂRCĂ 2014

24 COCIȘ/BÂRCĂ 2013, 161-175; COCIȘ/BÂRCĂ 2014, 206-208.

25 ALMGREN 1923, 91-92, 253-254, Group VII.

26 PÁRDUCZ 1931,144, Pl. XIV/6; SMISHKO 1948, 108, 112; SMISHKO 1952, 79, 80; SMISHKO 1960; SYMONOVICH 1955,28-30; SHRAMKO 1962, Fig. 98/1-2; KOLNÍK 1965, 189-199, 232; AMBROZ 1966, 72-73; PEŠKǍ̆ 1972, 106-108, Pl. 20; GODŁOWSKI 1970,13-19; GODŁOWSKI 1992, 26-27; GODŁOWSKI 1992a, 30-31; GODŁOWSKI 1994,78-79 GODŁOWSKI 2000, 77-78; KENK 1977, 183, 252-254, 328-334, Pl. 4, 27/3; GOROKHOVSKIJ 1987, 61-67; BARAN/GOROKHOVSKIJ/MAGOMEDOV 1990, 45-91; GOROKHOVSKIJ/GOPKALO 2004, 103-130; VADAY 1989, 78-79, Fig. 12/10-16; ANDRZEJOWSKI 2001, 55-63; MONCHYN'SKA 1999, 87111; MACZYŃSKA 2003,303-332; MACZYŃSKA 2011, 63-72, 301-309; OBLOMSKIJ 1991, 39-41, Fig. 3/1-4; OBLOMSKIJ 2003, Fig. 27/6; 32/3-4; 33/13; 43/23; 45/19, 68; LYUBICHEV 2003, 76-77, Fig. 4; LYUBICHEV 2008, 36-47; LYUBICHEV/DIDYK 2001-2002, 335-342; BAKUMENKO/BEJDIN/ GRIGOR'YANTS/DIDYK 2006, 69-95, 104; COCIŞ 2004, 133-135, no. 15941615; COCIȘ/BÂRCĂ 2013, 161-175; COCIȘ/BÂRCĂ 2014, 189-214.

27 PÁRDUCZ 1931, 144, Pl. XIV/6.

28 PATEK 1942, 68-69.

29 PÁRDUCZ 1941, 62

30 KENK 1977, 183, 252-254, 329-334, Pl. 4, 27/3.

31 KOLNÍK 1965, 232

32 PEŠKǍ̌ 1972, 107
}

Yu. Smishko ${ }^{33}$. A. Vaday revives the Sarmatian but also Dacian origin (respectively provincial Roman) of the discussed type $^{34}$. M. Maczyńska also believes that the origin of this type should be sought in the Sarmatian world of the Great Hungarian Plain and the area east of the Roman province of Dacia (Romanian Moldova and Wallachia), where the given brooches were born under the influence of brooch types specific to the provinces of Pannonia and Dacia, later diffusing to the northern territories ${ }^{35}$.

In 2011 M. Maczyńska resumed the discussion on the brooches of "Sarmatian" type from Europe ${ }^{36}$. Although the repertory in this recent study ${ }^{37}$ is much larger than in that of $2003^{38}$, it only partially includes the recent finds from the Przeworsk culture area, the eastern Germanic barbarian world, the Roman province of Dacia, and those in the Chernyakhov and Kiev culture areas. Unfortunately, the author's conclusions regarding these brooches are similar with those in the studies of 1999 and 2003, although the recently emerging contributions should have led to nuanced and amended statements expressed by M. Maczyńska.

Still in 2011, is published the paper tacking the brooches in group VII Almgren with vertical catchplate prepared by T. Schulte ${ }^{39}$, who divides the brooches in this group in three series, without yet taking into account as main factor their fastening mechanism (spring and chord design). Brooches of the type in the Ecser mould are classified as brooches of type Almgren VII, series 2, variations 28-2940. Alas, the absolute chronology of the brooches of the type is briefly re-discussed ${ }^{41}$, with a noted insufficient knowledge of the discussions and bibliographical references from the eastern territories, where such brooches were used.

Numerous studies concerning the brooches in group Almgren VII from the Chernyakhov and $\mathrm{Kiev}^{42}$ culture areas were issued in the last two decades, significantly completing extant information from previous works ${ }^{43}$. Following the examination of the brooches in group Almgren VII in the region east the Dnieper, M. V. Lyubichev believes their origin is the Wielbark environment ${ }^{44}$.

The most recent analysis of the brooches of type Almgren group VII, series I, headknob variation, external chord and vertical catchplate, as well as of the moulds and half-finished brooches, was carried out by S. Cociș and V.

\footnotetext{
${ }_{33}$ Apud GOROKHOVSKIJ/GOPKALO 2004, 106. By the presented finds, coming from the Upper Dniester river basin, M. Yu.Smishko (Cf. SMISHKO 1948, 108, 112; SMISHKO 1952, 79, 80; SMISHKO 1960) draws attention on the existence of another area with brooches of the type. The works drafted by M. Yu. Smishko provided for the first time also the typological constituents of the brooches in group Almgren VII from this region, valid to today.

${ }^{34}$ VADAY 1989, 78

${ }_{35}$ Cf. MONCHYN'SKA 1999, 87-111; MACZYŃSKA 2003, 303-332.

36 MACZYŃSKA 2011, 63-72.

7 MACZYŃSKA 2011, 301-309.

${ }^{38}$ Cf. MACZYŃSKA 2003, 303-332.

39 SCHULTE 2011.

${ }^{40}$ SCHULTE 2011, 127-131.

${ }^{41}$ SCHULTE 2011, 170.

${ }^{42}$ LYUBICHEV 2003, 76-77, Fig. 4; LYUBICHEV 2008, 36-47; LYUBICHEV/ DIDYK 2001-2002, 335-342; GOROKHOVSKIJ/GOPKALO 2004, 103-130; BAKUMENKO/BEJDIN/GRIGOR'YANTS/DIDYK 2006, 69-95, 104. For a broader presentation of the views expressed for the brooches in group Almgren VII from the cultural environments of the Eastern areas see COCIȘ/ BÂRCĂ 2014, 191-195.

${ }^{43}$ AMBROZ 1966,72-74

${ }^{44}$ LYUBICHEV 2003, 71-81; LYUBICHEV/DIDYK 2001-2002, 335-342.
} 
Bârcă ${ }^{45}$. Starting from the examination of the brooches in this variation from Roman Dacia and the Barbarian milieu by the Tisza river basin, the authors note that their diffusion area, as well as the workshops which produced them, clearly clusters in the Barbarian world, mainly or closely connected Germanic environment. Based on brooch, bronze and clay moulds and half-finished specimen finds, the authors concluded that the finds area evidencing the production of "Sarmatian" brooches, headknob and external chord variation (variation B2) includes, with one exception (Porolissum), the Germanic or Germanic influence world. Based on such facts, the authors also conclude that their association with the Sarmatian world and the observation they are of Sarmatian origin must be definitively abandoned. Furthermore, based on the analysis of all bronze and silver headknob and external chord brooches, they reach the conclusion that this brooch variation was born in the Przeworsk culture area, from where it spread southwards and eastwards. Another conclusion is that such brooches were adopted by the Sarmatian Iazyges from the Germanic populaces (most likely the Vandal) once with their arrival and settlement of the regions in the northern vicinity of the territory they inhabited. Last but not least, that the brooches in the headknob, external chord and vertical catchplate variation evidence contacts and cultural and economic interferences between various populations, clearly establishing the movement direction of Germanic populace groups starting with the last quarter of the 2 nd century AD.

\section{$* * *$}

The archaeological identification of the workshop is difficult, on both the territory of the former Roman empire and the Barbarian world of first centuries Europe. In contrast to other workshop types, like for instance, pottery or metalworking, they require a small area and are equipped with little inventory: small heating kilns, crucibles, moulds, tools for polishing, decorating, cutting and attaching. Overall, the hypothesis of an existent workshop within the Barbaricum, may be advanced based on the discovery of moulds, patterns, crucibles or half-finished objects ${ }^{46}$.

The analysis of the moulds and half-finished brooches showed that the finds area indicating the production of brooches of type Almgren group VII, series I, headknob, external chord and vertical catchplate variation comprises, except for the workshop at Porolissum ${ }^{47}$, the Germanic or Germanic influence world ${ }^{48}$, and that these centres produced the variation with external chord ${ }^{49}$. Such variant includes though many sub-variants ${ }^{50}$.

${ }^{45}$ COCIȘ/BÂRCĂ 2013; COCIȘ/BÂRCĂ 2014.

${ }^{46}$ COCIȘ/BÂRCĂ 2013, 163-164.

47 The exception of Porolissum, important Roman military, economic and trading centre located on the north-western border of the province of Dacia, which played a key role in the trade with the Barbarian world in the territories to the north and north-west of the province, may be firstly explained by the production of such Barbarian brooches by the Romans for the Barbarians. In fact, the production of other types of Barbarian brooches (some single-piece) is recorded in Dacia Porolissensis in two workshops (COCIS 2004, 35, Pl. LXIII, 946, COCIŞ 2007, 402-427). However, as previously mentioned, one should not exclude that in the area of the customs at Porolissum a Barbarian Germanic origin artisan was active (COCIS/BÂRCĂ 2013, 173).

${ }^{48}$ Cf. COCIȘ/BÂRCĂ 2013.

${ }^{49}$ Cf. COCIȘ/BÂRCĂ 2013.

${ }^{50}$ COCIȘ/BẤRCĂ 2014, 196.
Although based on the analysis of bronze and clay moulds and certain half-finished specimens, today may be cautiously identified around 10 workshops producing brooches in the discussed type ${ }^{51}$ (Fig. 8), one should agree that these crafting complexes very likely operated in many settlements ${ }^{52}$. They might have been mixed, with diversified production (brooches, domestic objects, military equipment etc.) or making specific items, namely in our case, brooches ${ }^{53}$. One should though not exclude the hypothesis of travelling artisans.

Chronologically, these production centres date to the last decades of the 2 nd century $\mathrm{AD}$ and early/first quarter of the 4th century AD, or broadly, according to the CentralEuropean chronology to stages B2/C1, C1a-C1b, C2 ${ }^{54}$.

Returning to the Ecser mould used for making brooches in sub-variation B2a1a1 from the typological classification drafted by S. Cociș and V. Bârcă ${ }^{55}$, it must be mentioned that M. Párducz dated the brooch type, based on associated material within Sarmatian graves from the Great Hungarian Plain, to the chronological timeframe between AD $180-250^{56}$. To the second half of the 2 nd century - early 3rd century AD dates such brooches in the Sarmatian milieu from the current territory of Szolnok county (Hungary) scholar A. Vaday ${ }^{57}$. Between the end of the 2 nd century AD and mid 3rd century AD date the brooches of the type in the Upper Tisza region ${ }^{58}$. For the same region, was also suggested a 3rd century AD dating ${ }^{59}$. Last but not least, for the DacianVandal area of the territories north-west the province of Dacia (Romania) was suggested their dating to stages B2/C1C1a (AD 150/160-210/220) ${ }^{60}$. The analysis of the specimens originating in a series of well dated features (graves) showed that brooches with external chord and headknob (B2a1a1) were used in the Sarmatian milieu of the Great Hungarian Plain mainly between the last two decades of the 2nd century $\mathrm{AD}$ and mid 3rd century AD (stages $\mathrm{C} 1 \mathrm{a}-\mathrm{C} 1 \mathrm{~b})^{61}$. Last but not least, discussed brooches are associated in some Sarmatian graves with bead strings, which points to their use especially by women. In some graves, the brooches in this sub-variant are associated with northern brooches and amber beads.

Numerous brooches in sub-variation B2a1a1 as well as a mould were discovered on the territory of the former

\footnotetext{
1 COCIS/BÂRCĂ 2013, Fig. 7; COCIȘ/BÂRCĂ 2014, Fig. 7. The Prusiek mould erroneously ascribed by us to making brooches of type Almgren group VII, series I (COCIȘ/BĂRCĂ 2013, 168, Fig. 3/4) was used for the casting of another fibula type. See to this effect MADYDA-LEGUTKO/RODZIŃSKANOWAK 2014, 285. Given the uncertain place of origin, both the halffinished specimen in the collection of the Museum of Mainz, believed to come from Hungary (BEHRENS 1954, 236, Fig. 10/2) and the bronze mould in the collection of Natural History Museum of Vienna (BEHRENS 1954, 235, no. 2; DRESCHER 1973, 57, Fig. 2/7) were not considered.

52 The single information on the role and status of the Barbarian craftsman in the society results from the furnishing of the grave at Prusiek (Cf. MADYDALEGUTKO/RODZIŃSKA-NOWAK/ZAǴORSKA-TELEGA 2007). Such graves of Barbarian artisans were also identified in the Przeworsk culture area (Cf. PRZYCHODNI 2005, 79-107).

53 COCIȘ/BÂRCĂ 2014, 208.

4 COCIȘ/BÂRCĂ 2013, 173; COCIȘ/BÂRCĂ 2014, 196.

5 COCIȘ/BÂRCĂ 2014, 196.

6 PÁRDUCZ 1956, 159.

VADAY 1989, 78; VADAY 2005a.

ISTVÁNOVITS 1990,103.

KOTIGOROŠKO 1995, 157.

GINDELE 2010, 131-134.

61 COCIȘ/BÂRCĂ 2014, 203; BÂRCĂ 2014, 117.
} 
Roman province of $\mathrm{Dacia}^{62}$, where they spread with one exception (Micia) in Dacia Porolissensis ${ }^{63}$. Numerically, most are known at Porolissum, from where also comes the bronze mould ${ }^{64}$.

Based on specimens from well dated archaeological contexts $^{65}$ it may be argued, like elsewhere ${ }^{66}$, that the use period of the brooches in sub-variant B2a1a1 in the province of Dacia is mainly framed to the last two decades of the 2 nd century AD and mid 3rd century AD. The relatively small number of brooches in this type (B2a1a1) within Dacia, the cluster of finds exclusively in the northern side of the province and their quasi-total lack from the rest of the Roman provinces by the Lower and Mid Danube, indicate they were not used by the Romans, but must be rather related to the presence by the borders of Dacia of the Vandals ${ }^{67}$, implicitly of Germanic craftsmen operating by the north-western border of this Roman province. Also, it must be mentioned that their extremely high numbers in the Barbaricum indicates that the brooches of the type are of Barbarian origin (Germanic) and that they reach Dacia via the latter.

Based on all the above, we may argue that the presence of the mould for brooch casting in the settlement at Ecser evidences the production of brooches in type Almgren group VII, series I, headknob, external chord and vertical catchplate variation (B2a1a1) in the territories inhabited by the Sarmatians in the Great Hungarian Plain ${ }^{68}$. Such facts suppose the existence nearby of a workshop for their making.

The research results carried out over the last two decades on these brooches and the ensuing conclusions ${ }^{69}$ clarify the use and production of such artefacts in the territories inhabited by the Sarmatians. Thus, based on the origin, diffusion area and workshops making them, but also on historical and archaeological facts, we believe that production of such brooches in this settlement must be rather ascribed to a Germanic origin artisan present to the territory inhabited by the Sarmatian Iazyges or in connection with the Germanic world. Also, we wish to mention that the Ecser settlement lies nearby the territories settled by the Germanic tribes, where this brooch variation was born.

Last but not least, the brooches in the headknob, external chord and vertical catchplate variation are artefacts which beside other brooch types and classes of Germanic objects evidence existing contacts and cultural and economic interferences between various populations, accurately establishing the southward and eastward movement

${ }_{62}$ COCIȘ 2004, 133-135, no. 1594-1615; COCIȘ/BÂRCĂ 2013, 170, Fig. 5/1a-1b ; COCIȘ/BÂRCĂ 2014, 197, 206-207, Fig. 1/1-20, 5/1a-1b.

${ }^{63}$ Cf. COCIȘ/BÂRCĂ 2014, 197, 209, Fig. 6.

${ }^{64}$ GUDEA/TAMBA 2008, 95-96. COCIŞ 2009, 152, Pl. 2; COCIŞ/BÂRCĂ 2013, 170, Fig. 5/1a-1b; COCIȘ/BÂRCĂ 2014, 206-207, Fig. 5/1a-1b.

${ }^{65}$ Four specimens from Porolissum, one from Potaissa, two from Ilişua and one specimen from Napoca.

${ }^{66}$ COCIȘ/BÂRCĂ 2014, 197

${ }^{67}$ COCIȘ/BÂRCĂ 2014, 197.

${ }_{68}$ As regards the half-finished specimen in the collection of the Museum of Mainz, deemed to likely come from Hungary (BEHRENS 1954, 236, Fig. $10 / 2$ ), we still believe that the uncertain place of origin makes impossible to argue that it is evidence of an existing workshop making such brooches in the Sarmatian environment of the current territory of Hungary (COCIȘ/BÂRCĂ 2013, 168; COCIȘ/BÂRCĂ 2014, 207).

${ }^{69}$ Cf. COCIȘ/BÂRCĂ 2013; COCIȘ/BÂRCĂ 2014. direction of certain Germanic population groups starting with the last quarter of the 2 nd century AD.

\section{REFERENCES}

\section{ALMGREN 1923}

Almgren, O., Studien über nordeuropäische Fibelformen der ersten nachchristlichen Jahrhunderte, mit Berücksichtigung der provinzialrömischen und südrussischen Formen, Mannus Bibliothek 32 (Leipzig: C. Kabitzsch).

\section{AMBROZ 1966}

Ambroz, A. K., Fibuly yuga evropejskoj chasti SSSR, Arkheologiya SSSR. Svod Arkheologicheskih Istochnikov D1-30 (Moskva: Nauka).

ANDRZEJOWSKI 2001

Andrzejowski, J., Późnororzymska zapinka, z Łubnic, woj. Świętokrzyskie, Wiadomości Archeologiczne LV, 55-63.

\section{BAKUMENKO/BEJDIN/GRIGOR'YANTZ/DIDYK 2006}

Bakumenko, K. I./Bejdin, G. V./Grigor'yantz, M. N./ Didyk, V. V., Fibuly rimskogo vremeni verkhov'ev Vorskly $i$ Severskogo Dontsa. In: Drevnosti rimskogo vremeni na Slobozhanshchine (Khar'kov: Kursor).

\section{BARAN/GOROKHOVSKIJ/MAGOMEDOV 1990}

Baran, V. D./Gorokhovskij, E. L./Magomedov, B. V., Chernyakhovskaya kul'tura i gotskaya problema, In: Tolochko, P. P. (ed.), Slavyane i Rus' (v zarubezhnoi istoriografii) (Kiev: Naukova Dumka), 30-78.

BATIZI et alii 2006

Batizi, Z./Dinnyés, I./Kővári, K./Kulcsár, V./Nagy, A./Patay, R./Rácz, T./Simon, L./Tari, E., Üllő 5.-Üllő 9. Lelőhely. In: Simon, L. (ed.), Régészeti kutatások masfelmmillió négyzetméteren. Autópálya és gyorsforgalmi utak építését megelőző régészeti feltárások Pest megyében 2001-2006, Pest Megyei múzeumi füzetek 7 (Szentendre: Pest Megyei Múzeumok Igazgatósága), 45-48.

\section{BÂRCĂ 2006}

Bârcă, V., Istorie şi civilizaţie. Sarmaţii în spaţiul est-carpatic (sec. I a. Chr. - inceputul sec. II p. Chr.) (Cluj-Napoca: Argonaut).

\section{BÂRCĂ 2011}

Bârcă, V., The fibulae in the North-Pontic Sarmatian Environment (1st C - first half of the 2nd C CE), Ephemeris Napocensis XXI, 7-35.

\section{BÂRCĂ 2014}

Bârcă, V., Sarmatian vestiges discovered south of the Lower Mures River. The graves from Hunedoara Timișană and Arad (Cluj-Napoca: Mega).

\section{BEHRENS 1954}

Behrens, G., Zur Typologie und Technik der provinzialrömischen Fibeln, Jahrbuh des Römisch Germanischen Zentralmuseums zu Mainz 1, 1954, 220-236.

COCIȘ 2004

Cociş, S., Fibulele din Dacia romană / The Brooches from Roman Dacia (Cluj-Napoca: Mega).

\section{COCIŞ 2007}

Cociş, S., Un nou atelier de fibule din Dacia Porolissensis. In: Nemeti, S., Fodoreanu, F., Cociş, Nemeti, I., Pîslaru, M. (eds.), Dacia Felix Studia Michaeli Bărbulescu Oblata (ClujNapoca: Tribuna), 402-413.

\section{COCIŞ 2009}

Cociş, S., Atelierele şi producţia de fibule de tip "sarmatic" (Varianta cu buton la cap şi coarda înaltă). In: Ţentea, O., Opriş, I. C. (eds.), Near and Beyond the Roman Frontier. Proceedings of a colloquim held in Târgovişte, 16-17 october 2008. Supplementum Cercetări Arheologice XVI (București: Muzeul Național de Istorie a României), 151-163.

COCIŞ/BÂRCĂ 2013 
Cociş, V./Bârcă, V., The workshops and production of "Sarmatian" brooches (Almgren Group VII, Series I), Dacia N. S. LVII, 161-175.

COCIŞ/BÂRCĂ 2014

Cociş, V./Bârcă, V., The "sarmatian" brooches (headknob and full catchplate variant, Almgren group VII, series I) in the Dacia province and the barbarian environment of the Tisza river basin, Dacia N. S. LVIII, 189-214.

\section{DRESCHER 1973}

Drescher, H., Der Guß von Kleingerät dargestellt an Funden aus provinzialrömischen Werkstätten. In: Early Medieval Studies 6 (Antikvarist Archiv 53) (Stockholm: Almqvist \& Wiksell), 48-62.

GINDELE 2010

Ghindele, R., Die Entwicklung der kaiserzeitlichen Siedlungen im Barbaricum im nordwestlichen Gebiet Rumäniens (SatuMare: Editura Muzeului Sătmărean).

GODŁOWSKI 1970

Godłowski, K., The chronology of the late Roman and early migration periods in Central Europa (Kraków: Nakladem Uniwersyteutu Jagiellonskiego).

\section{GODŁOWSKI 1992}

Godłowski, K., Die Chronologie der Jüngeren und Späteren Kaiserzeit in den Gebieten südlich den Sudeten und Karpaten. In: Godłowski, K., Madyda-Legutko, R. (eds.), Probleme der Relativen und Absoluten chronologie $\mathrm{ab}$ Latenèzeit bis zum Frühmittelalter. Materialien des III. Internationalen Symposiums: Grundprobleme der frühgeschichtlichen Entwicklung im nördlichen Mitteldonaugebiet Kraków - Karniowice 3.-7. December 1990 (Kraków: Secesja), 23-54.

GODŁOWSKI 1992a

Godłowski, K., Die Przeworsk-Kultur. In: Neumann, G., Seemann, H. (eds.), Beiträge zum Verstännis der Germania des Tacitus, Teil II, Abhandlungen der Akademie der Wischaften in Göttingen, Philologisch-Historische Klasse 3, 195 (Göttingen: Vandenhoeck \& Ruprecht), 9-90.

GODŁOWSKI 1993

Godłowski, K., Die Barbaren nördlich der Westkarpaten und das Karpatenbecken. Einwanderungen, politische und militärische Kontakte, Specimina Nova IX, 1993 (1994), 65-89.

GODŁOWSKI 1994

Godłowski, K., Die Chronologie der germanischen Waffengräber in der jüngeren und späten Kaiserzeit. In: C. von Carnap-Bornheim (ed.), Beiträge zu römische und barbarischer Bewaffnung in den ersten vier nachchristlichen Jahrhunderten. Acten des 2. Internationalen Kolloquiums in Marburg a. d. Lahn, 20. Bis 24. Februar 1994 (Lublin/ Marburg: Vorgeschichtliches Seminar der PhilippsUniversität), 169-178.

\section{GODŁOWSKI 2000}

Godłowski, K., Die Vorrömischen Eisenzeit und Römische Kaiserzeit im östlichen Mitteleuropa und in Osteuropa. In: Fibel und Fibeltracht. Reallexikon der Germanischen Altertumskunde 8 (Berlin-New-York: De Gruyter), 68-86.

\section{GOROKHOVSKIJ 1987}

Gorokhovskij, E. L., Rannij etap chernyakhovskoj kul'tury (k probleme khronologicheskoj definitsii). In: Kultura wielbarska w młodszym okresie rzymskim (Lublin: Uniwersytet Marii Curie-Skłodowskiej), 61-67.

GOROKHOVSKIJ/GOPKALO 2004

Gorokhovskij, E. L./Gopkalo, O. V., Fibuly VII gruppy O Al'mgrena $\mathrm{v}$ areale Chernyakhovskoj kul'tury. In: Arkheologiya davnikh slovyan. Doslidzhennya i materiali (Kiev: IA NANU), 103-130.

GUDEA/TAMBA 2008
Gudea, N./Tamba, D., Despre o jumătate de tipar bivalv din bronz, pentru turnat fibule prin metoda cerei pierdute, Revista Bistritei XXII, 95-100.

\section{GSCHWANTLER/WINTER 1991}

Gschwantler, K., Winter, H., Bronzewerkstätten in der Austria Romana, ein Forschungsprojekt. Römisches Österreich 17-18, 107-142.

\section{CZOPEK/PODGÓRSKA-CZOPEK 2004}

Czopek, S./Podgórska-Czopek, J., Osada z okresu rzymskiego w Grodzisku Dolnym, stan. 22 w świtle dotychcyasowzch badań. In: Łuczkiewicz, P. (ed.), Europa Barbarica. Ćwierć wieku archeologii w Masłomęczu IV. Monumenta Studia Gothica 4 (Lublin: Uniwersytet Marii Curie-Skłodowskiej), 71-77.

ISHTVANOVICH, KUL'CHAR 2016

Ishtvanovich, E./Kul'char, V., Zaimstvovannye elementy $\mathrm{v}$ kul'ture sarmatov Vengerskoj nizemennosti. In: Luk'yashko, S. I. (ed.), Antichnaya tsivilizatsiya i varvarskij mir Ponto-Kaspijskogo regiona. Materialy Vserossijskoj nauchnoj konferentsii s mezhdunarodnym uchastiem, posvyashchennoj 70-letnemu yubileyu B. A. Raeva, Kagal'nik, 20-21 oktyabrya 2016 g. (Rostov na Donu: Izdatel'stvo YuNTs RAN), 119-124.

ISTVÁNOVITS 1990

Ishtvanovich, E., A Felső-Tisza-vidék legkorábbi szarmata leletei, 2-3. századi sírok Tiszavasváriból, A Nyíregyházi Jósa KENK 1977 András Múzeum Évkönyve XXVII-XXIX, 1984-1986, 83-133.

Kenk, R., Studien zum Beginn der jüngeren römischen Kaiserzeit in der Przeworsk- Kultur, dargestellt am Beispiel der Gräberfelder von Chorula und Spicymierz, Bericht der Römisch-Germanischen Kommission 58, 161-446.

\section{KOLNÍK 1965}

Kolník, T., K typológii a chronológii niektorých spón z mladsey doby rimskej na juhozápadnom Slovensku, Slovenská Archeologia XIII/1, 183-236.

\section{KOTIGOROŠKO 1995}

Kotigoroško, V., Ţinuturile Tisei superioare în veacurile III $\hat{\imath}$. e. n. - IV e. n. (Perioadele La Téne şi romană) (Bucureşti: Vavila Edinf).

KŐVÁRI et alii 2006

Kővári, K./Kulcsár, V./Mérai, D./Nagy, A./Pesty, K./Voicsek, V., Ecser 7. lelőhely, In: Simon, L. (ed.), Régészeti kutatások masfelmmillió négyzetméteren. Autópálya és gyorsforgalmi utak építését megelőző régészeti feltárások Pest megyében 2001-2006, Pest Megyei múzeumi füzetek 7 (Szentendre: Pest Megyei Múzeumok Igazgatósága), 21-25.

\section{KREN/POLLAK 2008}

Kren, H./Pollak, M., Kleinhöflein, Fundberichte aus Österreich 46, 681-682.

\section{LYUBICHEV 2003}

Lyubichev, M. B., K voprosu o vremeni poyavleniya pamyatnikov chernyakhovskoj kul'tury na dneprodonetskom vodorazdele, Rossijskaya Arkheologiya 3, 71-81.

\section{LYUBICHEV 2008}

Lyubichev, M. B., Etnokul'turnyj podtekst rasprostraneniya fibul gruppy Al'mgren VII vostochnee Dnepra. In: Drevnosti 2006-2008. Khar'kovskij istoriko-arkheologicheskij ezhegodnik (Khar'kov: Khar'kovskij natsional'nyj universitet imeni V. N. Karazina), 36-47.

\section{LYUBICHEV/DIDYK 2001-2002}

Lyubichev, M. B./Didyk, B. B., Ob odnoj gruppe fibul pozdnerimskogo vremeni $v$ dnepro-donetskoj lesostepi, Stratum plus 4, 335-342.

MACZYŃSKA 2003

Maczyńska, M., Przeworsk-Kultur. Jüngere und späte 
Römische Kaiserzeit. In: Beck, H., Geuenich, D., Steuer, H. (eds.), Reallexikon der Germanischen Altertumskunde 23 (Berlin-New-York: De Gruyter), 553-567.

MACZYŃSKA 2011

Maczyńska, M., Die früvölkerwanderungszeitliche Hortfund aus Łubiana Kreis Kościerzyna (Pommern), Bericht der Römisch-Germanischen Kommission 90, 7-482.

MADYDA-LEGUTKO/RODZIŃSKA-NOWAK/ZAGÓRSKA-TELEGA 2007

Madyda-Legutko, R./Rodzińska-Nowak, J./ZagórskaTelega, J., Wyniki dalszych badań na cmentarzysku kultury przeworskiej w Prusieku, stan. 25, pow. Sanok, Rocznik Przemyski, Archeologia 43/2, 61-69.

MADYDA-LEGUTKO/RODZIŃSKA-NOWAK/ZAGÓRSKA-TELEGA 2011

Madyda-Legutko, R./Rodzińska-Nowak, J./ZagórskaTelega, J., Opatów, Fpl 1. Ein Gräberfeld der PrzeworskKultur im nordwestlichen Kleinpolen. Katalog (1), Tafeln (2). Fundacja Monumenta Archaeologica Barbarica XV (Warszava-Kraków: Fundacja Monumenta archaeologica barbarica).

MADYDA-LEGUTKO/RODZIŃSKA-NOWAK 2014

Madyda-Legutko, R./Rodzińska-Nowak, J., Pochówek metalurga z cmentarzyska kultury przeworskiej w Prusieku, stan. 25, pow. sanocki. In: Madyda-Legutko, R., RodzińskaNowak, J. (eds.), Honoratissimum assensus genus est armis laudare: studia dedykowane Profesorowi Piotrowi Kaczanowskiemu z okazji siedemdziesiątej rocznicy urodzin (Kraków: Towarzystwo Wydawnicze "Historia Iagellonica"), 277-290.

MONCHYN'SKA 1999

Monchyn'ska, M., O tak nazyvaemykh „sarmatskikh” fibulakh v Srednej i Vostochnoj Evrope. In: Sto let chernyakhovskoj kul'ture (Kiev), 87-111.

OBLOMSKIJ 1991

Oblomskij, A. M., Etnicheskie protsessy na vodorazdele Dnepra i Dona v I-V vv. n. e. (Moskva-Sumy:UFK).

OBLOMSKIJ 1999

Oblomskij, A. M., O vremeni poyavleniya Chernyakhovskogo naseleniya na territorii Dneprovskogo Levoberezh'y. In: Sto let chernyakhovskoj kul'ture (Kiev), 26-38.

OBLOMSKIJ 2002

Oblomskij, A. M., Dneprovskoe lesostepnoe Levoberezh'e v pozdnerimskoe i gunnskoe vremya (Moskva: Nauka).

PATEK 1942

Patek, E., Verbreitung und Herkunft der römischen Fibeltypen in Pannonien (Disertationes Pannonicae II, 19) (Budapest).

PÁRDUCZ 1931

Párducz, M., A Nagy Magyar Alföld rómaikori leletei, Dolgozatok VII (Szeged), 74-186.

PÁRDUCZ 1941

Párducz, M., A szarmatakor emlékei Magyarországon I / Denkmäler der Sarmatenzeit Ungarns I (Archaeologia Hungarica XXV) (Budapest: Akadémiai Kiado).

PÁRDUCZ 1956

Párducz, M., Beiträge zur Geschichte der Sarmaten in Ungarn im II. Und III. Jahrhundert, Acta Archaeologica Academiae Scientiarum Hungaricae VII, 139-182.

PEŠKǍ̌ 1972

Peškař, I., Fibeln aus der römischen Kaiserzeit in Mähren (Praha: Československa akademie věd).

PRZYCHODNI 2005

Przychodni, A., Die Besttungen der Schmiedhandwerker aus dem Gräbfeld der Przeworsk-Kultur in Korytnica, kr. Jedrzejów, woiw. Świetokrzyskie, Fundstelle 1/22, Acta Archaeologica Carpathica 40, 79-107.

\section{SCHULTE 2011}

Schulte, L., Die Fibelen mit hohem Nadelhalter (Almgren Grupe VII) (Neumünster: Wachholtz Verlag).

SHRAMKO 1962

Shramko, B. A., Drevnosti Severskogo Dontsa (Khar'kov: Izdatel'stvo Khar'kovskogo gosuniversiteta imeni A. M. Gor'kogo).

SMISHKO 1948

Smishko, M. Yu., Doba „poliv pohovan” v zakhidnykh oblastyakh URSR, Arkheologiya (Kyiv) 2, 98-130.

SMISHKO 1952

Smishko, M. Yu., Ranneslavyanskaya kul'tura Podnestrov'ya $\mathrm{v}$ svete novykh arkheologicheskikh dannykh, Kratkie soobshcheniya Instituta istorii material'noy kul'tury AN SSSR 44, 67-82.

SMISHKO 1960

Smishko, M. Yu., Karpats'ki kurgany pershoi polovyny I tysyacholittya nashoi ery (Kyiv: Akademiya nauk URSR).

STUPPNER 1991

Stuppner, A., Bernhardstahl, Fundberichte aus Österreich 29, 236.

SYMONOVICH 1955

Symonovich, E. A., O datirovke poseleniya pervykh vekov nashei ery v Luke Vrublevetskoj, Kratkie soobshcheniya Instituta istorii material'noy kul'tury AN SSSR 57, 23-32.

TEJRAL 2006

Tejral, J., Die germanischen Gießereiwerkstatt in Pasohlávky (Bez. Břeclav). Ein Beitrag zur Frage der Fernhandels und Kulturbeziehungen nach den Markomannenkriegen, Památky Archeologické 97, 133-170.

VADAY 1989

Vaday, A., Die sarmatischen Denkmäler des Komitats Szolnok (Antaeus 17-18, 1988-1989) (Budapest: Archäologisches Inst. der UAW).

VADAY 2005

Vaday, A. H., Adatok a szarmaták fémmúvességéhez (Tiszaföldvár-Téglagyár), A Szántó Kovács Múzeum Évkönyve 7, 151-198.

VADAY 2005a

Vaday, A., Corpus des römischen Funde im Barbaricum, VOSS 1998 Ungarn, Band 1, Komitat Szolnok (Budapest: Akaprint).

Voss, H. U., Zum Vergleich römischer und germanischer Feinschiedetechnik an Hand ausgewählter Sachgüter, 307313. In: Voss, H. U., Hammer, P., Luty J., Römische und germanische Bunt - und Edelmetallfunde im Vergleich, Archäometallurgische Untersuchungen ausgehend von den elbgermanischen Körpergräbern, Bericht der RömischGermanischen Kommission 79, 108-381. 


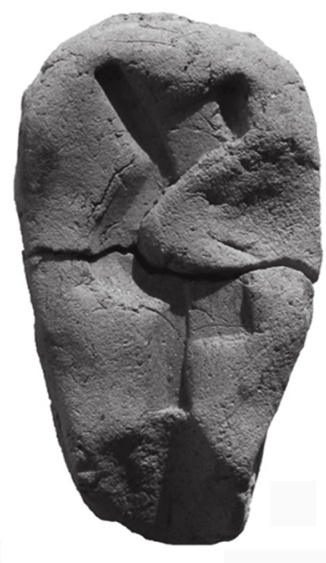

1

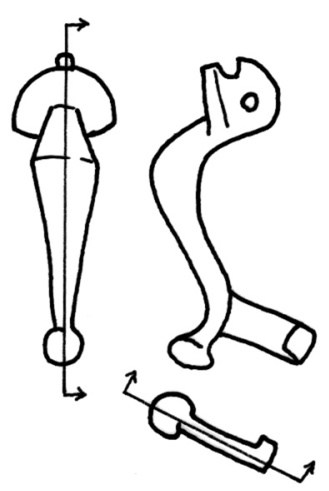

3
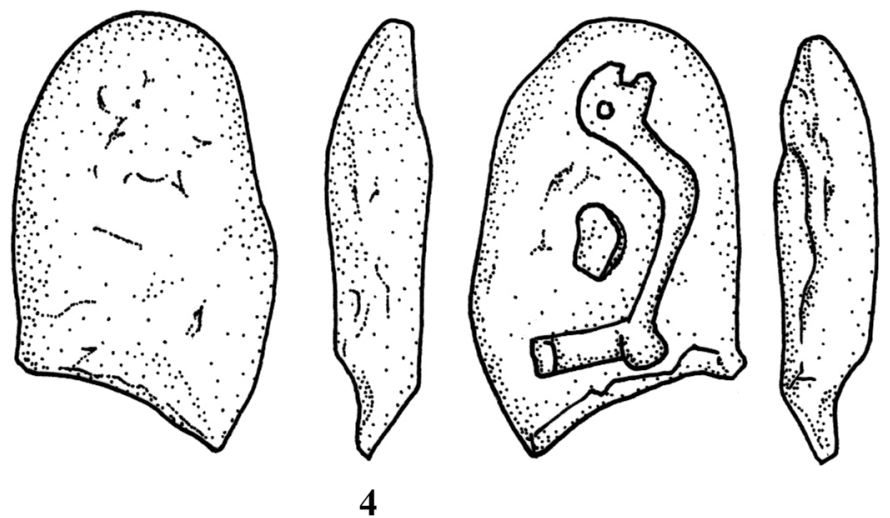

0
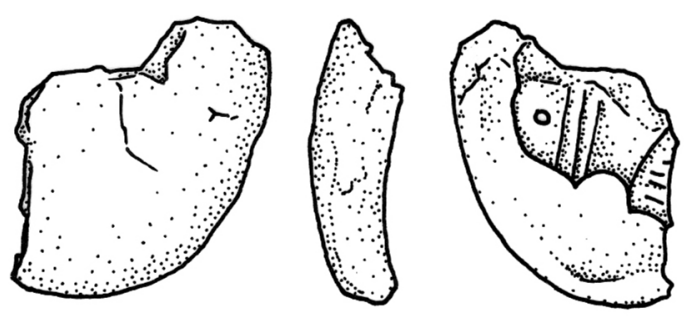

2

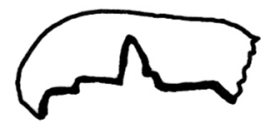

(
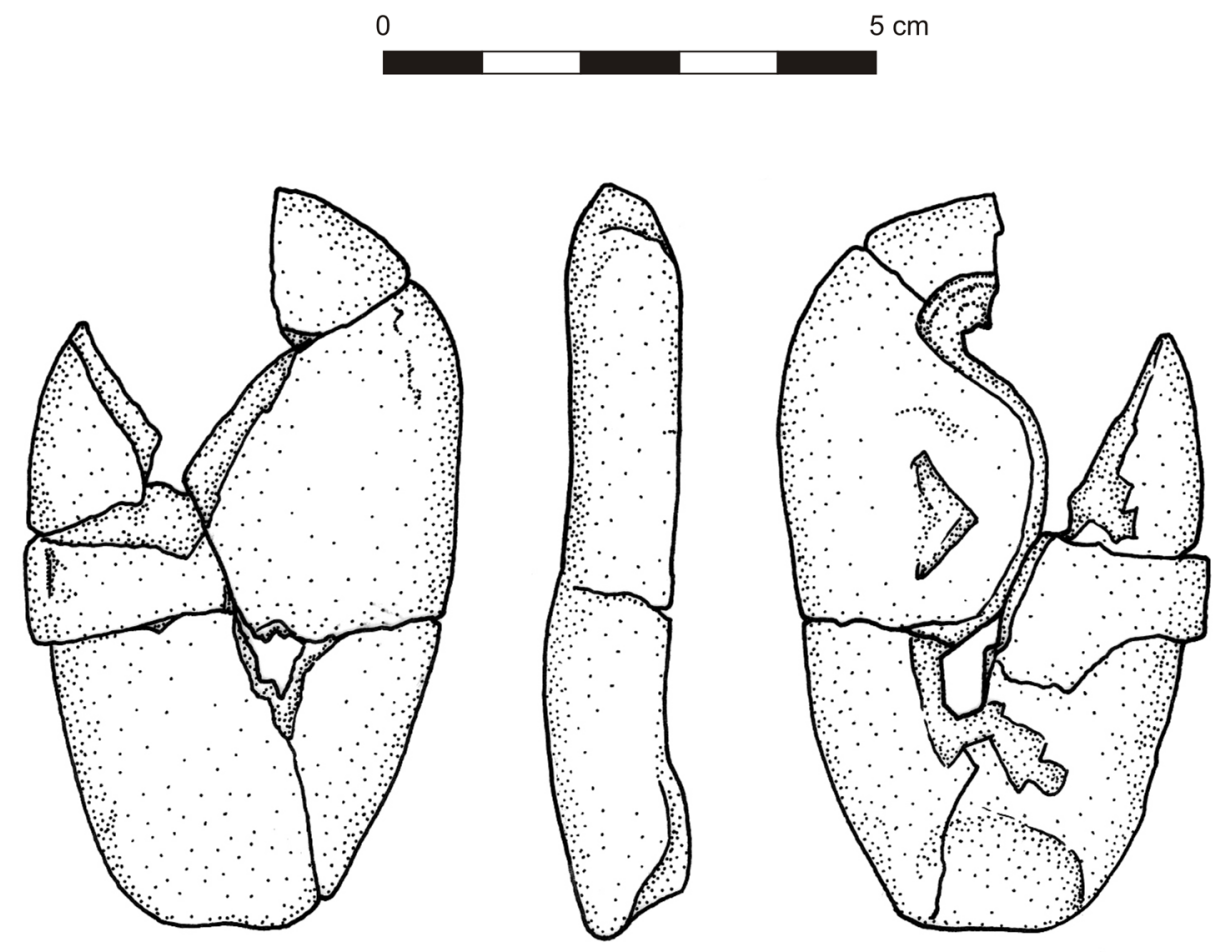

5

Fig. 1. 1. The clay Ecser mould (after ISHTVANOVICH/KUL'CHAR 2016); 2. Clay mould of a knee brooch from Tiszaföldvár-Téglagyár; 3. Reconstruction of knee brooch from the Tiszaföldvár-Téglagyár mould; 4. Clay mould for a knee brooch from Tiszaföldvár-Téglagyár; 5 . Clay mould for strongly profiled brooch from Tiszaföldvár-Téglagyár (after VADAY 2005). 

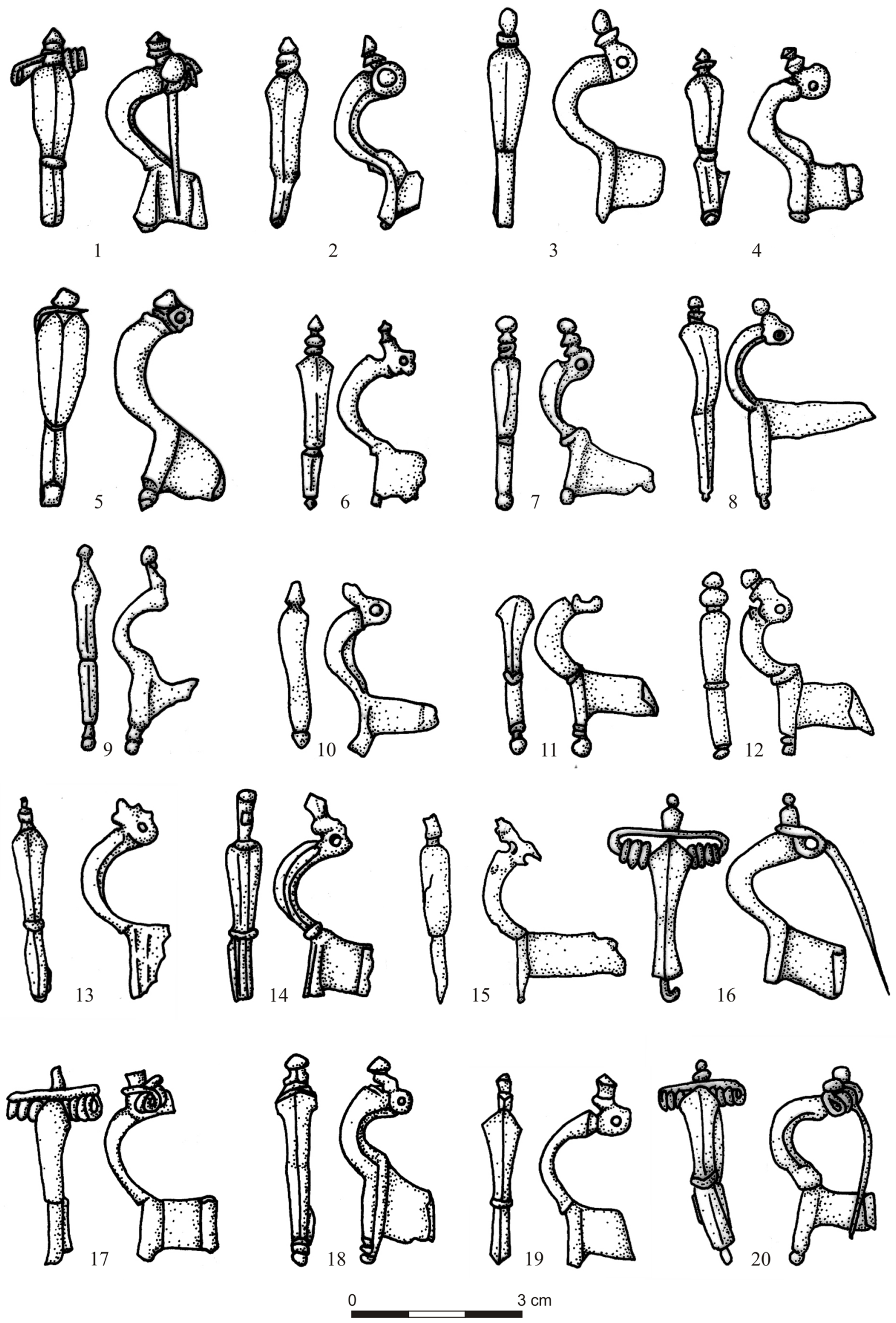

Fig. 2. Brooches in the variation with headknob, external chord and vertical catchplate (Almgren group VII, series I) from Roman Dacia. 1-12. Porolissum; 13. Ilişua; 14-15. Bucium; 16. Gherla; 17-18. Potaissa; 19-20. Micia (after COCIȘ/BÂRCĂ 2014). 

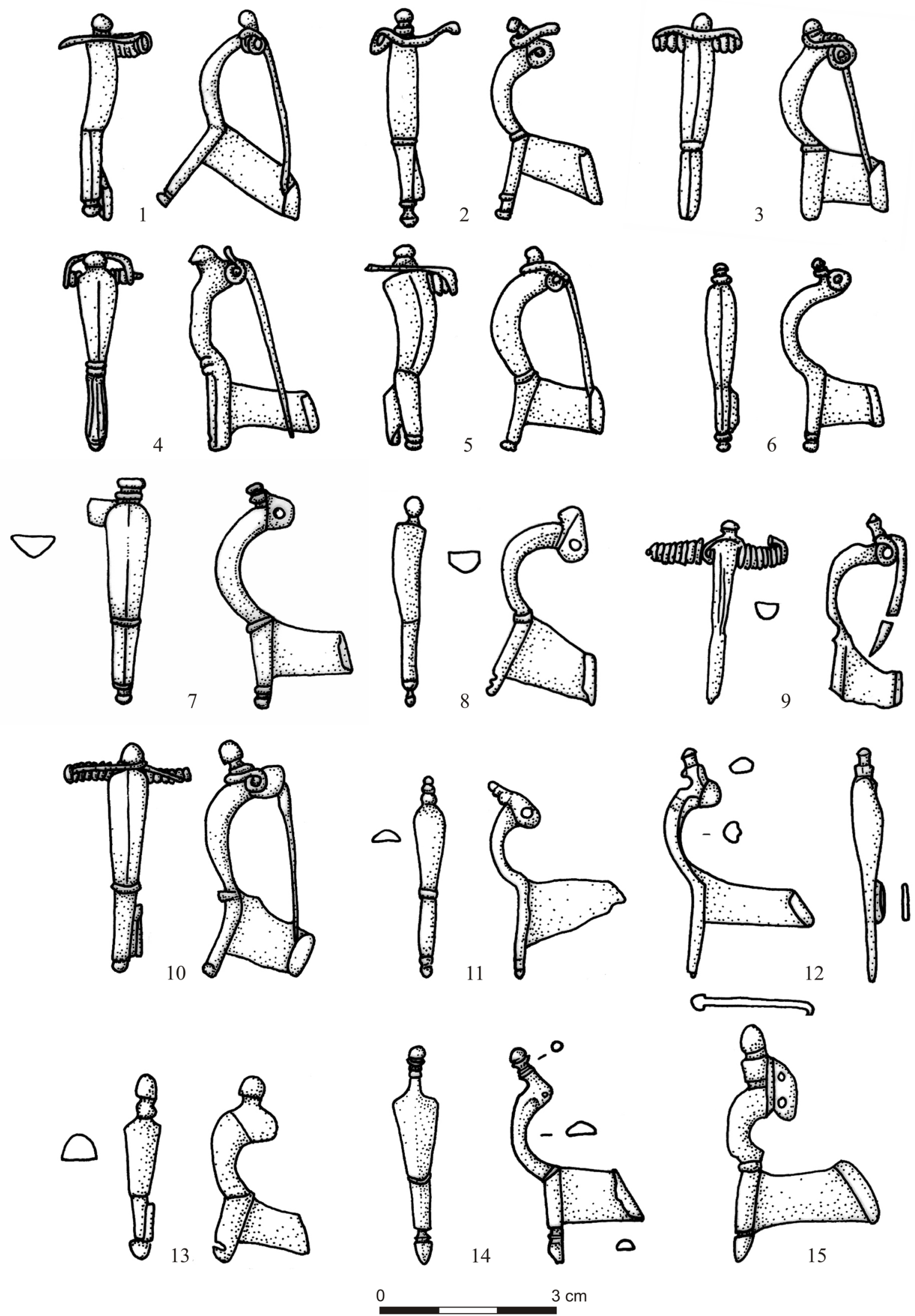

Fig. 3. Brooches in the variation with headknob, external chord and vertical catchplate (Almgren group VII, series I) from the Barbaricum. 1. Kunhegyes; 2. Törökszentmiklós-Surján; 3. Jászberény-Négyszállás; 4. Jászberény-Csegelapos; 5. Szolnok-Szandaszőlős; 6. Túrkeve; 7. Hunedoara Timișană; 8. Fényeslitke; 9. Beregsurány; 10. Esztár-Tanácsháza; 11. Medieşul Aurit; 12. Culciu Mic; 13. Doh; 14. Berveni; 15. Humenné (after COCIȘ/ BÂRCĂ 2014). 

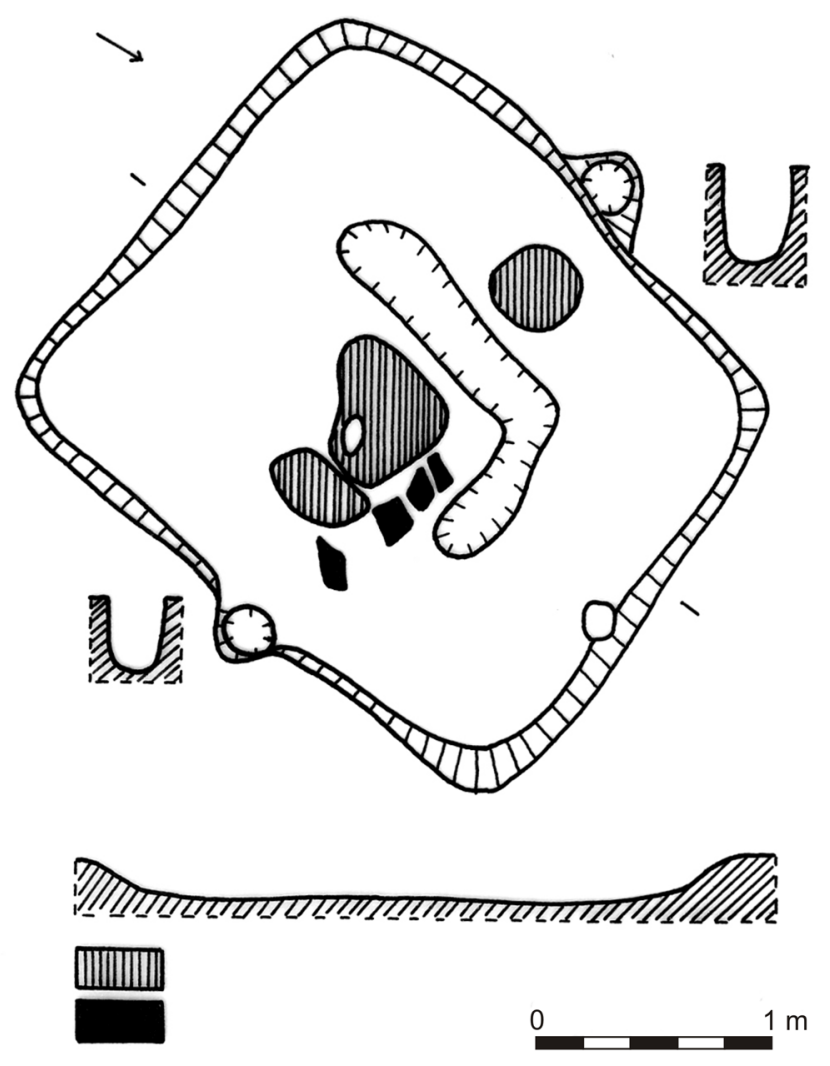

1
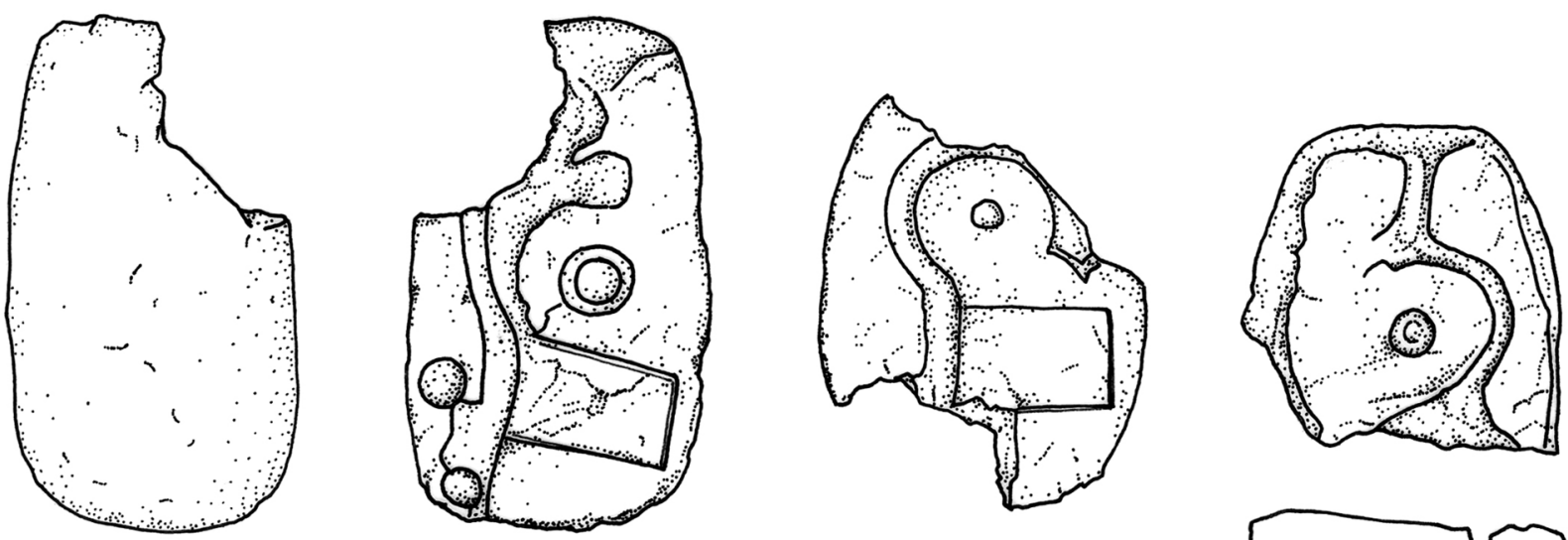

2
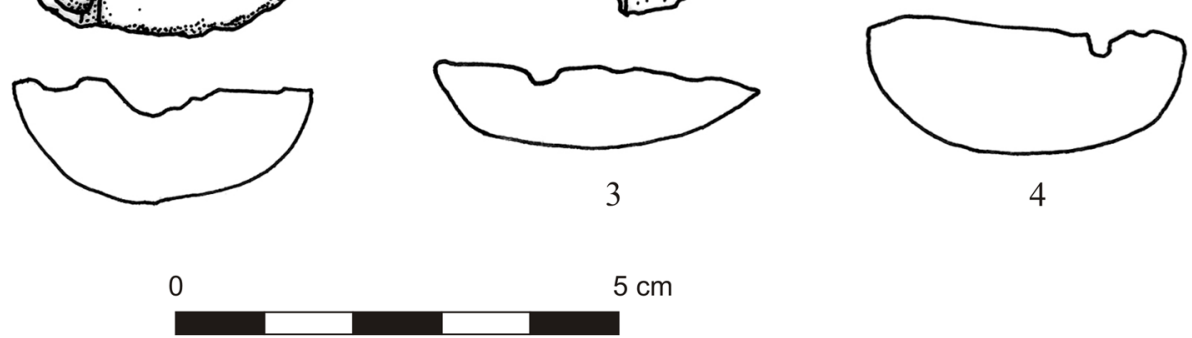

Fig. 4. 1. Layout of the workshop at Pasohlávky (after TEJRAL 2006); 2-4. Clay moulds for brooches in the variation with headknob, external chord and vertical catchplate (Almgren group VII, series I) from Pasohlávky (after TEJRAL 2006). 

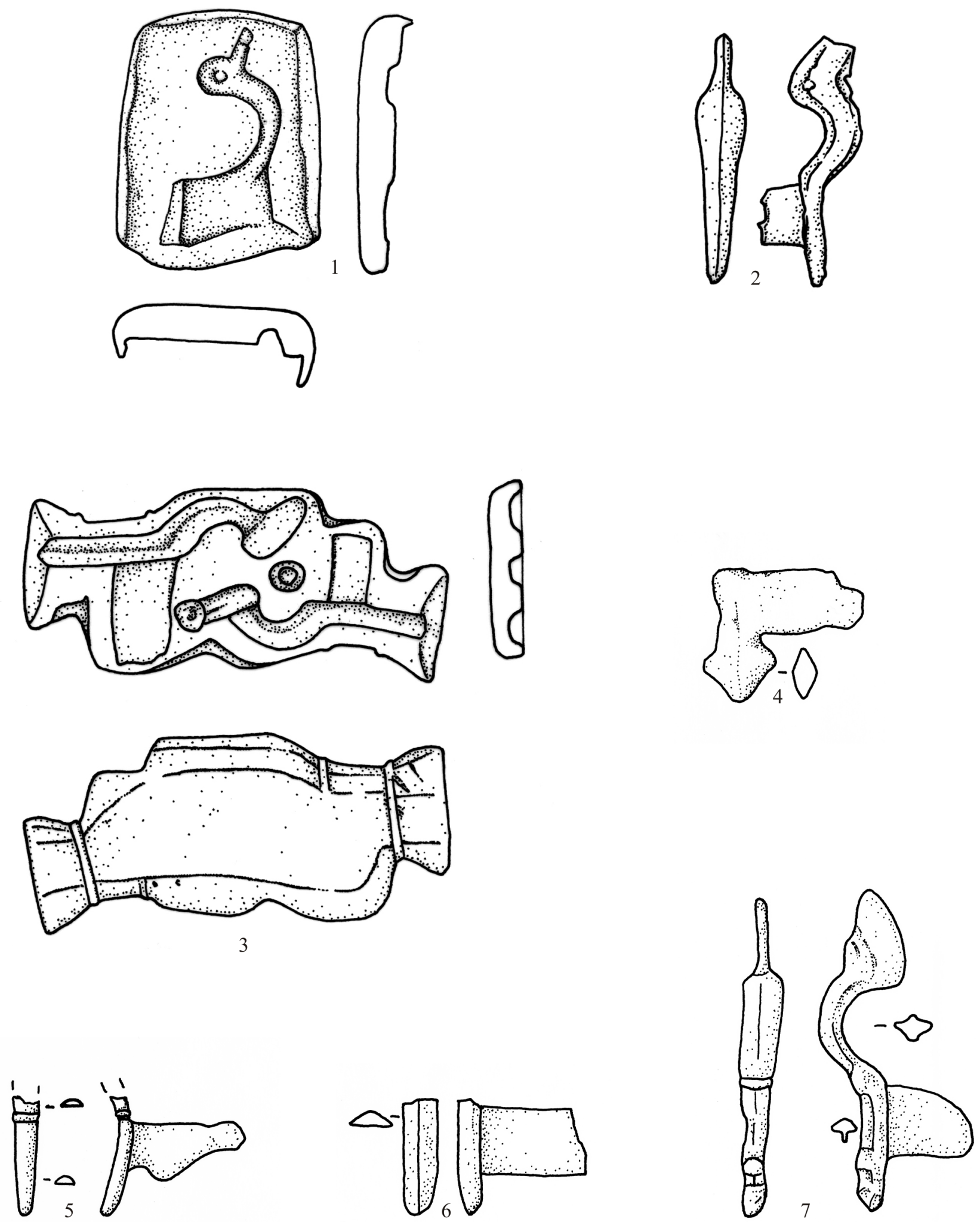

Fig. 5. 1. The bronze mould of Kleinhöflein (after KREN/POLLAK 2008);2. Half-finished brooch with headknob, external chord and vertical catchplate (Almgren group VII, series I) from Bernhardstahl (after STUPPNER 1991); 3. Bronze mould in the collection of the Natural History Museum of Vienna (after GSCHWANTLER/WINTER 1991); 4-7. Half-finished brooches from Paseki (4) and Ogul'tzy (5-7) (after BAKUMENKO/BEIDIN/GRIGOR'YANTZ/ DIDYK 2006). 

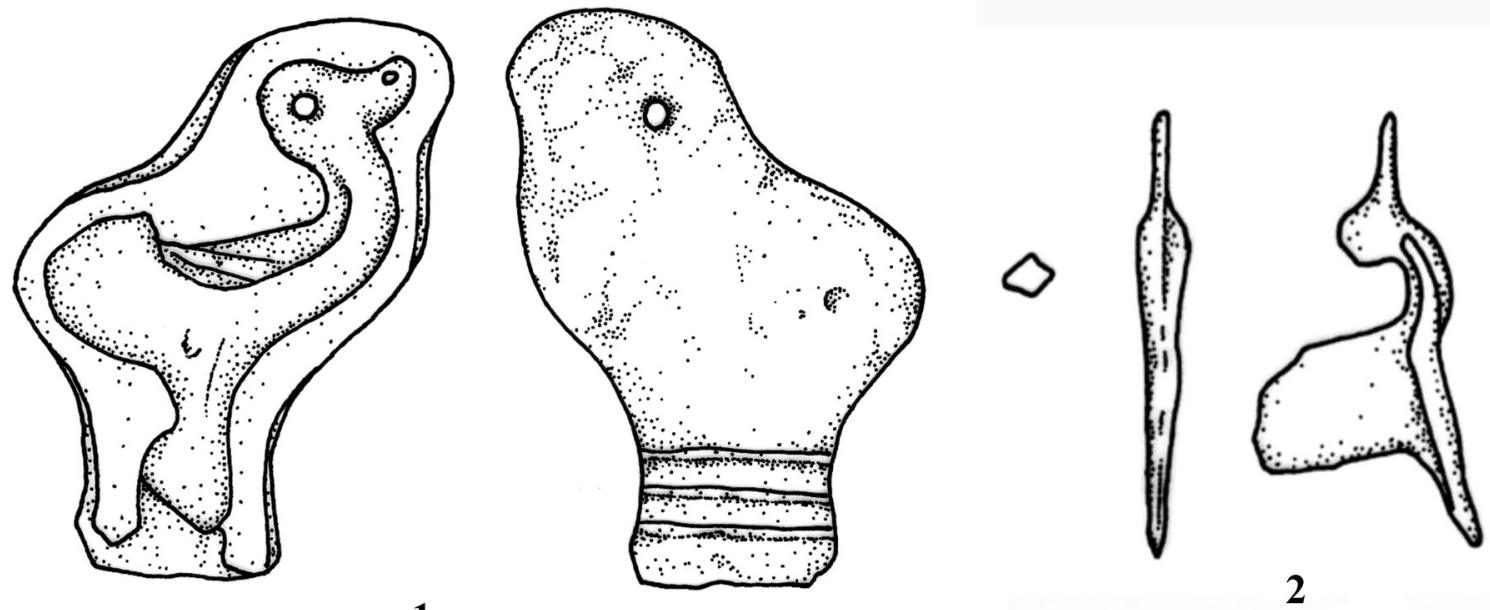

2

1

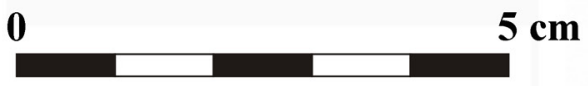

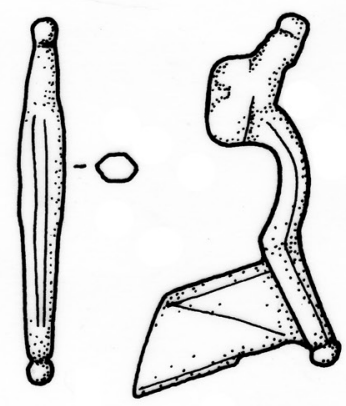

3

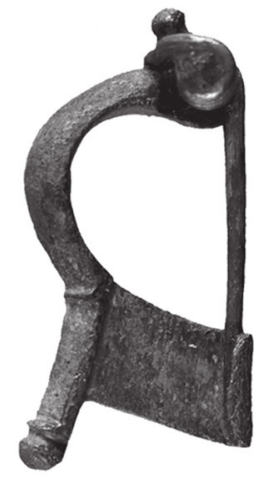

5
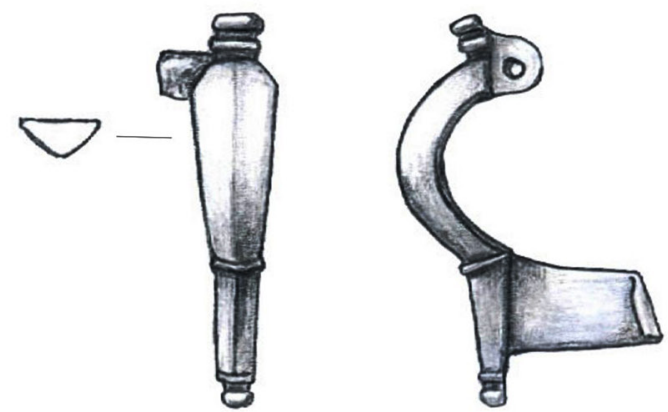

4

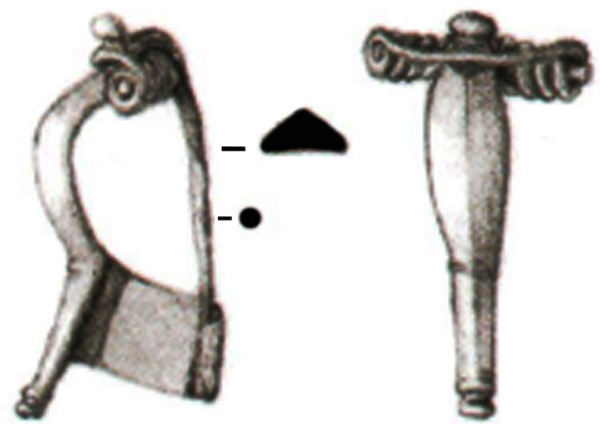

6

Fig. 6. 1. The bronze mould of Neunheilingen (after WALTHER 1996); 2-3. Half-finished brooches with headknob, external chord and vertical catchplate (Almgren group VII, series I) from Grodzisko Dolne (after CZOPEK/PODGÓRSKA-CZOPEK 2004); 4-6. Brooches with headknob, external chord and vertical catchplate from Hunedoara Timișană (4) (after BÂRCĂ 2014), Üllő (5) (after ISHTVANOVICH/KUL'CHAR 2016) and Ecser (6) (after KŐVÁRI et alii 2006). 6 - Without scale. 

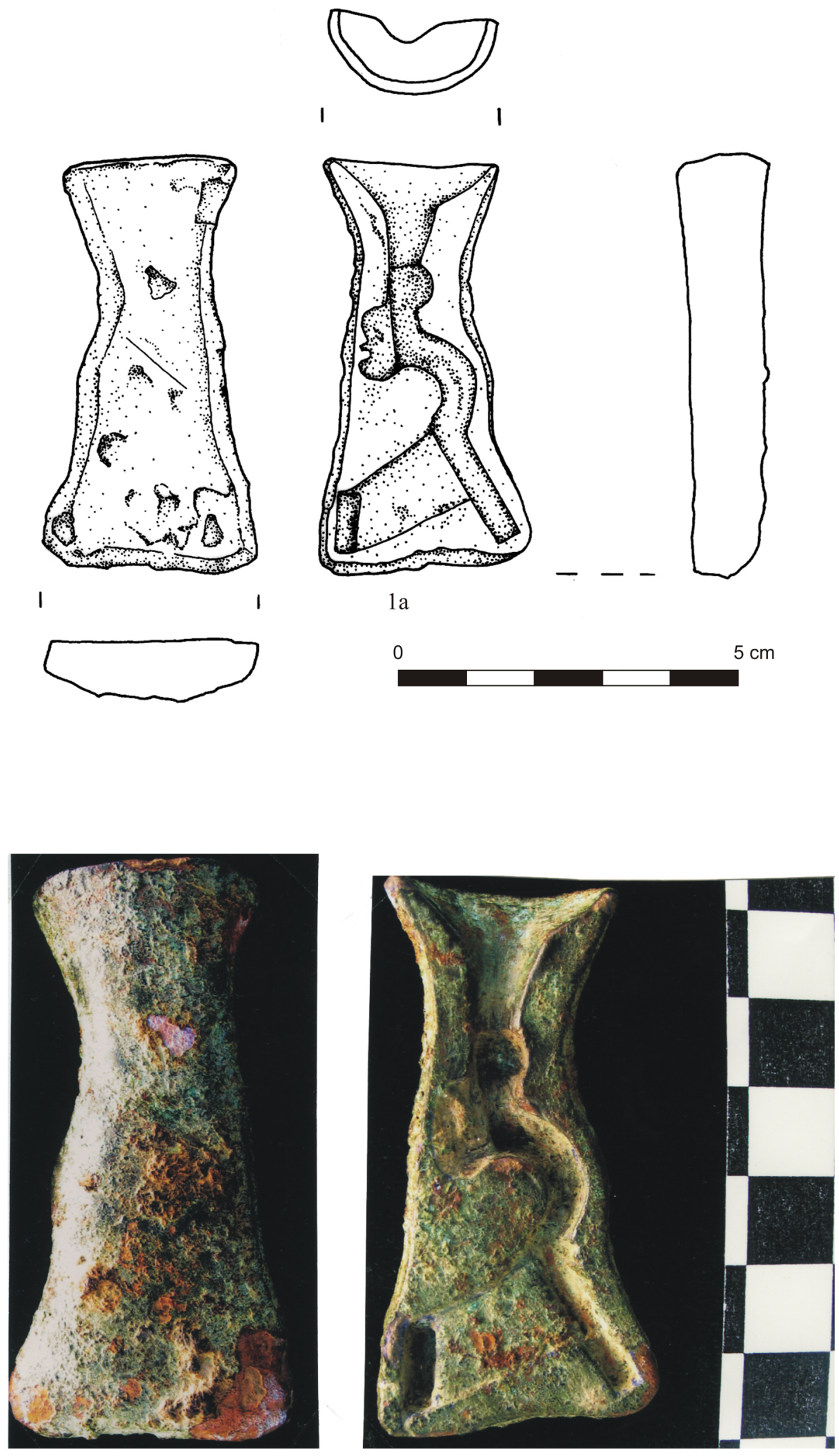

$1 b$

Fig. 7. 1a-1b, Bronze mould of Porolissum (after GUDEA/TAMBA 2008). 

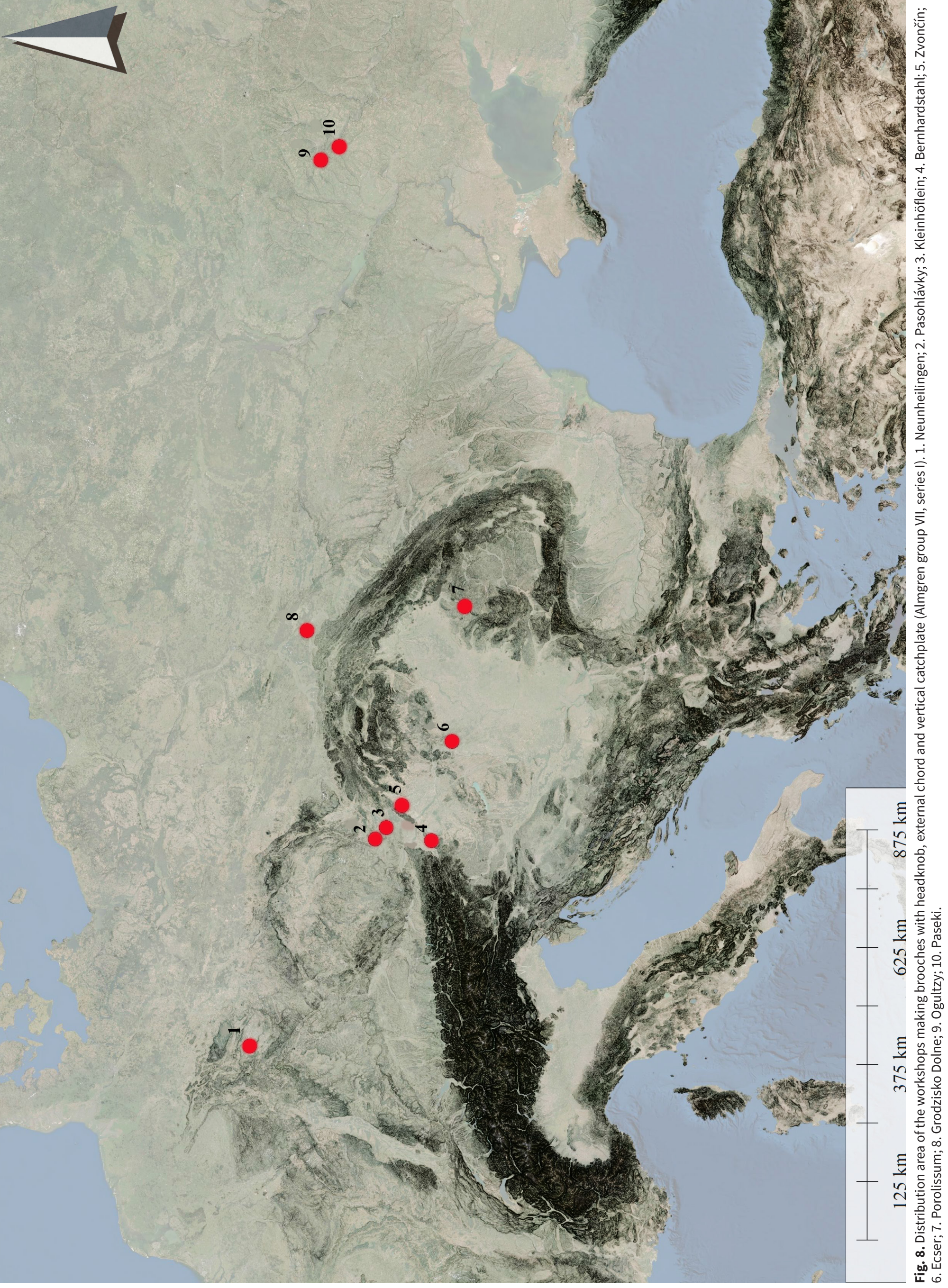